"Evaluation of Wells and Coppersmith (1994) Earthquake and Fault Relationships in the New Zealand Context" by Mark Stirling, David Rhoades, Kelvin Berryman (IGNS), EQC funded report 97/249-December 1998.

"Ash Predictions, How Successful Were they?" by AW Hurst and BJ Scott (IGNS), EQS funded report 97/268-October 1998.

These reports may be borrowed by applying to the NZSEE Administrative Secretary, PO Box 48 086, Silverstream, Upper Hutt.

\section{WORLD EARTHQUAKES OF MAGNITUDE 6.0 AND GREATER.}

April 18- August 2000.

Data from the U.S. National Information Service.

Date Lat. Long. Depth Mag.

APR 18 20.569S 176.509W 220 5.9 Fiji Islands Region.

APR $2151.419 \mathrm{~N}$ 178.169W $33 \quad 6.0$ Andreanof Islands, Aleutian Is.

ML 6.2 (PMR). Felt strongly on Adak.

APR $2328.334 S 62.942 W 607$ 7.0 Santiago Del Estero Prov., Arg.

Felt in the La Rioja and Buenos Aires areas.

APR 23 28.366S 62.924W 610 6.1 Santiago Del Estero Prov., Arg.

MAY 04 1.146S 123.597E $33 \quad 7.6$ Sulawesi, Indonesia. At least 46 people killed, 254 injured, extensive damage and power outages occurred in the Luwuk area, Sulawesi and on nearby islands. Eighty percent of buildings were damaged or destroyed on Banggai. Damage also occurred on Peleng. Dozens of houses damaged (VII) and a local market destroyed by fire at Luwuk. Much of the damage east of Luwuk and on Peleng was caused by a local tsunami with estimated wave heights up to 6 meters. Felt (V) at Gorontalo and Palu; (IV) at Manado and Tolitoli, Sulawesi. Felt (IV) at Balikpapan, Borneo.

MAY 04 17.803S 178.568W 515 6.5 Fiji Islands Region.

MAY $06 \quad 11.274 S \quad$ 165.349E $33 \quad 6.3$ Santa Cruz Islands.

MAY 08 4.485S 150.009E 5106.1 New Britain Region P.N.G.

MAY 12 22.988S 66.743W 244 6.2 Juyjuy Province, Argentina. Felt (VI) at Antofagasta, Calama, Chaquicamata, Copiapo, Mejillones and Sierra Gorda; (V) at caldera, Chanaral Diego de Almagro, Iquique, Tierra Amarilla and Tocopilla: (IV) Arica Portillos and Pozo Almante; (III) at Parinacota, Chile.

MAY 12 35.960N 70.657E 108 6.3 Hindu Kush Region. Felt strongly in Badakhshan Province: also felt in the Kabul area, Afghanistan; felt in the Peshawar area, Pakistan and Dushanbe area, Tajikistan. Also felt in the Tashkent area, Ubekistan.

MAY 14 4.316S 123.211E $33 \quad 6.2$ Banda Sea.

MAY $21 \quad 71.224 \mathrm{~N} \quad 8.245 \mathrm{~W} \quad 10 \quad 6.0$ Jan Mayen Island Region.

MAY $2611.322 \mathrm{~N} \quad 139.103 \mathrm{E} 33 \quad 6.0 \mathrm{~W}$. Caroline Islands, Micronesia.

JUN $0244.546 \mathrm{~N} \quad 129.996 \mathrm{~W} 10 \quad 6.2$ Off Coast Of Oregon.

JUN $03 \quad 35.537 \mathrm{~N} \quad 140.396 \mathrm{E} \quad 70 \quad 6.1$ Near East Coast Of Honshu, Japan. One person injured in Chiba Prefecture. Felt in the Tokyo area Recorded (5L JMA) in northern Chiba and (4 
JMA) in southern

Chiba and southern

Ibaraki Prefectures.

JUN $044.773 S \quad 102.050 E \quad 337.9$ Southern Sumatera, Indonesia.

At least 97 people killed, 1,900 people injured and extensive damage and landslides in the Bengkulu area; injuries and damage on Enggano. Felt (IV) at Lampung and Palembang; (III) at Jakarta. Felt in much of southern Sumatera. Felt in Singapore; also felt at Johor Bahru, Kuala Lumpur and Petaling Jaya, Malaysia.

JUN $06 \quad 40.651 \mathrm{~N} \quad 32.917 \mathrm{E} \quad 33 \quad 6.0$ Turkey.

At least two people killed, more than 80 people injured and at least 4,600 homes destroyed or damaged in the Cerkes-CubukOrta area. Felt strongly in the Ankara area. Also felt in much of north- central Turkey and along the Black Sea coast.

JUN 06 5.091S 102.764E 33 6.2 Southern Sumatera, Indonesia.

Felt (IV) at Lampung and (III) at Jakarta.

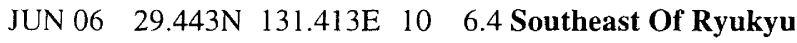
Islands.

Recorded (3 JMA) on Kuchino-shima, Amami-shima and parts of eastern Kyushu; (2 JMA) on Kikai-jima, much of southern Kyushu and western Honshu.

JUN $07 \quad 26.837$ N 97.223E $33 \quad 6.4$ Myanmar.

Many buildings damaged in Yunnan Province, China. Felt in northern Myanmar and in Arunachal Pradesh, India.

JUN 07 4.652S 101.982E 33 6.7 Southern Sumatera, Indonesia.
JUN 09 5.138S 152.556E 33 6.3 New Britain Region, P.N.G.

JUN 09 5.616S 102.645E 33 6.0 Southern Sumatera, Indonesia.

JUN $09 \quad 11.355 \mathrm{~S} \quad 161.923 \mathrm{E} \quad 33 \quad 6.1$ Solomon Islands.

JUN $09 \quad 30.527 \mathrm{~N}$ 137.661E $487 \quad 6.2$ Southeast Of Honshu, Japan.

JUN $10 \quad 23.818 \mathrm{~N} \quad 121.212 \mathrm{E} \quad 33 \quad 6.4$ Taiwan.

Two people died from heart attacks and 36 others injured in the Nan-fou area. Landslides and rockslides blocked a number of highways in central Taiwan. Felt from Kao-hsiung to Taipei. Also felt (IV) in Hong-Kong. Recorded (6 TAP) in western Nan-fou; ( 5 TAP) in Yun-lin, western Taj-nan and northern Tai-tung counties. Recorded (5 TAP) at Chang-Hua, Chia-i and Hualien; (4 TAP) at Cheng-Kung, Miao-li and Taichung; (3 TAP) at Ilan, Kao-hsiang, Tainan and Taipei. Also recorded (4 TAP) at Ma-kung, Peng-hu Tao; (1 JMA) on Iriamote-jima and Yonaguni-jima, Ryukyu Islands

JUN $11 \quad 50.596 \mathrm{~S} \quad 139.735 \mathrm{E} \quad 10 \quad 6.6$ Western IndianAntarctic Ridge.

JUN 1425.487 S $\quad 178.005 E \quad 605 \quad 6.4$ South Of Fiji Islands.

JUN $14 \quad 4.656 \mathrm{~N} \quad 127.570 \mathrm{E} \quad 88 \quad 6.3$ Talaud Islands, Indonesia.

JUN $14 \quad 17.800 S \quad 176.166 \mathrm{E} 33 \quad 6.0$ Fiji Islands Region.

JUN $15 \quad 29.492 \mathrm{~N} \quad 132.044 \mathrm{E} \quad 33 \quad 6.1$ Southeast Of Shikoku, Japan. Recorded (2 JMA) on Amami-O-shima and in much of southern Kyushu; (1 JMA) as far as Hiroshima Prefecture, Honshu. 
JUN $16 \quad 33.926 S \quad 70.100 \mathrm{~W} \quad 1206.4$ Chile-Argentina Border Region.

Felt (VI) at Rancagua,

San Fernando, and

Valparaiso; (V)

Curico, Parral,

Quillota, Quilpue, San

Antonio, Santo

Domingo, Santiago,

and Talca; (IV)

Concepcion, Los

Andes, Petorca and

San Felipe; (III) at

Illapel, La Serena and

Ovalle, Chile. Felt

(IV) at Mendoza and

San Juan, Argentina.

JUN $17 \quad 64.029$ N 20.396W $10 \quad 6.5$ Iceland.

One person injured in the Vestmannaeyjar

Islands. At least 30

houses destroyed or

damaged in the Hella

area. Landslides-

rockslides blocked

some roads and

utilities disrupted in

the epicentral area.

Felt in much of

southern Iceland.

JUN $18 \quad 13.962 S \quad 97.473 \mathrm{E} \quad 10 \quad 7.8$ South Indian Ocean.

Felt strongly in the

Cocos Islands. Felt (II)

at Bengkulu, Jakarta and Padangpanjang,

Indonesia. Local tsunami in the Cocos

Islands.

JUN $20 \quad$ 14.171S 97.634E $10 \quad 5.8$ South Indian Ocean.

JUN $21 \quad 63.971 \mathrm{~N} \quad 20.699 \mathrm{~W} \quad 10 \quad 6.5$ Iceland.

At least 12 houses

destroyed, some

damaged in the

Grimsnes area. Water

lines broken in the

Eyrarbakki-Selfoss-

Stokkseyvi area. Felt

in much of southern

Iceland including

Reykjavik.

JUN $21 \quad 14.170 \mathrm{~N} \quad 144.840 \mathrm{E} \quad 111 \quad 6.0$ Mariana Islands.

Felt in the areas of

Agana, Andersen AFB

and Yigo, Guam. Also

felt on Saipan.

JUN $23 \quad 1.356 \mathrm{~N} \quad 126.274 \mathrm{E} \quad 62 \quad 6.1$ Northern Molucca

Sea.
JUN $25 \quad 31.311 \mathrm{~N} \quad 131.152 \mathrm{E} \quad 10 \quad 6.2 \mathrm{Kyushu}$, Japan

Recorded (4 JMA) in

the Kanoya area and ( 3

JMA) in southern

Miyazaki and other

parts of Kagoshima

Prefectures, Kyushu.

Also recorded (3

JMA) on Tanega-

shima.

$\begin{array}{lllll}\text { JUL } 01 & 34.211 \mathrm{~N} & 139.134 \mathrm{E} & 10 & 6.2 \text { Near S. Coast Of }\end{array}$

Honshu, Japan.

One person killed,

several injured and

damage to buildings,

landslides and power

outages on Kozu-

shima. Recorded (6L

JMA) on Kozu-shima,

(5L JMA) on Nii-jima,

(4 JMA) on Miyakejima; ( 3 JMA) on Oshima and ( $2 \mathrm{JMA}$ ) on Hachijo-jima. Also recorded (4 JMA) at Kawazu; (3 JMA) at

Tateyama and

Yokohama; (2 JMA)

at Tokyo and many other parts of central Honshu.

JUL 07 51.464N 179.994E $69 \quad 6.4$ Rat Islands, Aleutian Islands.

Felt (V) on Adak.

JUL $08 \quad 34.683 N \quad 139.274 E \quad 10 \quad 5.9$ Near S. Coast Of

Honshu, Japan.

Recorded (5L JMA)

on Kozu-shima; ( 3

JMA) on Miyake-jima;

(2 JMA) in southern

Chiba and eastern

Shizuoka Prefectures;

(1 JMA) as far north

as Niigata Prefecture,

Honshu.

JUL $10 \quad 46.860 \mathrm{~N}$ 145.403E $358 \quad 6.2$ Sea Of Okhotsk Recorded ( 1 JMA) in the Kushiro area, Hokkaido, Japan.

JUL $11 \quad 57.508 \mathrm{~N} \quad 154.335 W 53 \quad 6.7$ Kodiak Island Region, Alaska. Some minor damage on Kodiak. Felt throughout southern Alaska and as far north as Fairbanks. 
JUL $15 \quad 34.364 \mathrm{~N} \quad 139.254 \mathrm{E} \quad 10 \quad 6.1$ Near S. Coast of Honshu, Japan.

At least eight people injured, 20 homes damaged and landslides on Nii-jima. Recorded (6L JMA) on Nii-jima, (5L JMA) on O-shima, (4 JMA) on Kozu-shima, ( 3 JMA) on Miyake-jima and (2 JMA) on

Hachijo-jima. Also recorded (4 JMA) at Tateyama and Yokohama; (3 JMA) at Ito, Sagamihara, Shimoda, Suwa,

Tokyo and Yokosuka

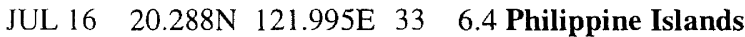
Region.

At least seven people injured; a church bell tower and some houses destroyed (VII RF); utilities disrupted and landslides blocked a highway on Basco.

JUL $167.746 S \quad 150.903 E 336.6$ New Britain Region, P.N.G.

JUL $16 \quad 12.309 \mathrm{~S} \quad 166.433 \mathrm{E} \quad 33 \quad 6.1$ Santa Cruz Islands.

JUL 1736.239 N 70.986E 1426.3 Hindu Kush Region, Afghanistan.

Two people killed at Peshawar, Pakistan. Felt strongly in northern Pakistan. Some minor damage in the AmritsarSrinagar area, India. Also felt strongly in the Kabul area, Afghanistan.

JUL $20 \quad 36.625$ N $140.961 E \quad 496.0 \quad$ Near East Coast Of Honshu, Japan. Felt in the Tokyo area. Recorded (5L JMA) at Hitachi-ota, Kasama, Mito and Takahagi; (4 JMA) at Koriyama, Imaichi, Nasu and Shirakawa.

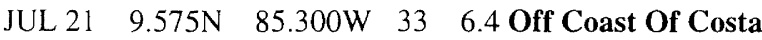
Rica.

Felt in the San Jose area.

\section{JUL $30 \quad 33.952 \mathrm{~N} \quad 139.435 \mathrm{E} \quad 10 \quad 6.5$ Southeast Of}

Honshu, Japan.

One person injured, road damage and landslides on Miyakejima. Felt in the Tokyo area. Recorded $(6 \mathrm{~L}$

JMA) on Miyake-jima; (5L JMA) on Kozushima and Nii-jima; (3 JMA) on Hachijojima and O-shima. Also recorded (3 JMA) in southern Chiba, eastern Kanagawa and eastern Shizuoka Prefectures. Recorded (1 JMA) as far as Hyogo and

Wakayama

Prefectures.

JUL $31 \quad$ 16.721S $\quad$ 174.523E $33 \quad 6.1$ Fiji Islands Region.

JUL $31 \quad 29.285 S \quad 176.336$ W $33 \quad 5.9$ Kermadec Islands Region.

AUG $03 \quad 12.047 \mathrm{~S} \quad 166.464 \mathrm{E} \quad 33 \quad 6.6$ Santa Cruz Islands.

AUG 04 48.753N 142.293E $10 \quad 6.8$ Sakhalin Island, Russia.

At least eight people injured, 19,100 people left homeless, 1,390 buildings damaged and a landslide destroyed roads and power lines in the UglegorskMakarov area. Estimated 920,000 US dollars damage. Recorded (1 JMA) in the Wakkanai area, Hokkaido and on Rishiri-to.

AUG 06 28.829N 139.497E 394 7.3 Bonin Islands, Japan Region.

Recorded (3 JMA) on Hachijo-jima and in southern Chiba, northeastern Fukushima and eastern Kanagawa Prefectures, Honshu. Recorded (1 JMA) as far as southern Aomori Prefecture, Honshu.

AUG 07 6.968S 123.468E 6496.5 Banda Sea.

AUG $09 \quad 15.693 \mathrm{~S} \quad 167.980 \mathrm{E} \quad 33 \quad 6.3$ Vanuatu Islands. 
AUG 09 18.353N 102.341W 33 6.5 Michoacan, Mexico. One person injured in the Playa Azul area. Felt in the states of Colima, Guanjuato, Guerrero, Jualisco, Morelos, Michoacan Oaxaca, and Puebla. Also felt at Mexico City.

AUG 09 16.889S 174.363E $33 \quad 6.4$ Fiji Islands Region.

AUG $12 \quad 3.008 \mathrm{~S} \quad 136.117 \mathrm{E} \quad 33 \quad 6.0$ Irian Jaya,

Indonesia.

AUG $14 \quad 9.356 \mathrm{~S} \quad 153.816 \mathrm{E} \quad 10 \quad 6.0$ D'entrecasteaux Islands Region.

AUG $15 \quad 31.411 \mathrm{~S} \quad 179.708 \mathrm{E} 358 \quad 6.6$ Kermadec Islands Region.

Felt widely on the North Island, New Zealand from Whakatane to Wellington.

AUG $19 \quad 43.803 \mathrm{~N} \quad 147.173 \mathrm{E} \quad 63 \quad 6.0$ Kuril Islands.

AUG 21 53.028S 45.999W $33 \quad 6.1$ South Atlantic Ocean.

AUG 24 6.045S 102.749E $33 \quad 5.8$ Southwest Of Sumatera, Indonesia.

AUG $28 \quad 4.018 S \quad 127.515 E \quad 16 \quad 6.8$ Banda Sea.

Felt strongly on Ambon, Indonesia.

AUG $28 \quad 3.882 S \quad 127.511 \mathrm{E} \quad 10 \quad 6.1$ Seram, Indonesia. Felt strongly on Ambon, Indonesia.

AUG $28 \quad 4.142 S \quad 127.253 E \quad 33 \quad 6.5$ Banda Sea.

SIGNIFICANT NEW ZEALAND EARTHQUAKES. May - August 2000

MAY $01 \quad 40.30 \mathrm{~S} \quad$ 176.43E $\quad 48 \quad 4.130$ km east-south-east of Dannevirke. Felt Dannevirke and district.

MAY $0240.81 \mathrm{~S} \quad 176.84 \mathrm{E} \quad 33 \quad 4.154 \mathbf{k m}$ east of Castlepoint.

MAY 03 40.09S 174.93E $25 \quad 3.820$ km south-southwest of Wanganui. Felt Marton and Tawa.
MAY 04 35.39S 178.41E $12 \quad 5.2261$ km north-northeast of White Island

MAY $0435.33 \mathrm{~S} \quad 178.46 \mathrm{E} \quad 33 \quad 4.7269$ km north-northeast of White Island.

MAY $0740.41 \mathrm{~S} \quad$ 177.25E $\quad 33 \quad 4.074 \mathrm{~km}$ south-east of Waipukurau.

MAY $0831.00 \mathrm{~S} \quad 179.90 \mathrm{E} \quad 3006.0285 \mathrm{~km}$ south-west of Raoul Island.

Felt at Whakatane and Wellington.

MAY $1236.67 \mathrm{~S} \quad 177.27 \mathrm{E} \quad 12 \quad 4.094 \mathrm{~km}$ north of White Island.

MAY $1340.20 \mathrm{~S} \quad 174.19 \mathrm{E} \quad 118 \quad 4.580 \mathrm{~km}$ west of Wanganui. Felt Marton and Raumati.

MAY $1436.73 \mathrm{~S} \quad 177.30 \mathrm{E} \quad 25 \quad 4.789 \mathrm{~km}$ north of White Island.

MAY 15 36.54S $177.48 \mathrm{E} \quad 12 \quad 4.2111 \mathrm{~km}$ north-northeast of White Island.

MAY 16 40.03S $\quad 174.84 \mathrm{E} \quad 1145.524$ km west-southwest of Wanganui. Felt from Taranaki to Christchurch.

MAY 17 37.97S $176.65 \mathrm{E} \quad 1445.413$ km north-northwest of Kawerau.

MAY $18 \quad 41.22 \mathrm{~S} \quad 174.26 \mathrm{E} \quad 45 \quad 3.720 \mathrm{~km}$ north-east of Picton. Felt Wellington

MAY $2038.60 \mathrm{~S} \quad 175.88 \mathrm{E} \quad 5 \quad 5.020 \mathrm{~km}$ north-west of Taupo. Felt Taupo.

MAY $2241.19 \mathrm{~S} \quad$ 173.65E $\quad 78 \quad 4.130 \mathrm{~km}$ east of Nelson. Felt Marlborough and Kapiti coast.

MAY 23 46.70S 165.63E 124.0170 km west-south west of Tuatapere.

MAY $2344.86 \mathrm{~S} \quad 167.00 \mathrm{E} \quad 5 \quad 4.475$ km west-southwest of Milford Sound.

MAY $2637.17 \mathrm{~S} \quad 177.32 \mathrm{E} \quad 5 \quad 4.040 \mathrm{~km}$ north-northeast of White Island.

MAY $3042.97 \mathrm{~S} \quad 176.42 \mathrm{E} \quad 33 \quad 4.0$ Approx. 200 km east of Cheviot.

MAY $3146.37 \mathrm{~S} \quad 169.80 \mathrm{E} \quad 5 \quad 3.517 \mathrm{~km}$ south-southwest of Balclutha. 